\title{
13 years of MOPITT operations: lessons from MOPITT retrieval algorithm development
}

\author{
H. M. Worden ${ }^{1}$, M. N. Deeter ${ }^{1}$, D. P. Edwards ${ }^{1}$, J. Gille ${ }^{1}$, J. Drummond ${ }^{2}$, L. K. Emmons ${ }^{1}$, G. Francis ${ }^{1}$, S. \\ Martínez-Alonso ${ }^{1}$ \\ ${ }^{1}$ National Center for Atmospheric Research (NCAR), Boulder, CO. \\ ${ }^{2}$ Dept. of Physics and Atmos. Sci., Dalhousie University, Halifax, Nova Scotia, Canada \\ hmw@ucar.edu
}

\begin{abstract}
The Measurements of Pollution in the Troposphere (MOPITT) instrument on the NASA Terra platform has now acquired over thirteen years of global tropospheric carbon monoxide (CO) observations, forming the longest satellite record for an important pollutant. MOPITT products are routinely exploited for characterizing $C O$ sources and for analyzing air quality. For retrieving $C O$ concentrations in the lower troposphere, MOPITT is equipped with both thermal-infrared and near-infrared channels.
\end{abstract}

\section{INTRODUCTION}

Measurements of carbon monoxide (CO) from space have been critical for understanding global atmospheric chemistry and emissions. Sources of $\mathrm{CO}$ are incomplete combustion (both fires and fossil fuels) and hydrocarbon oxidation. $\mathrm{CO}$ is destroyed primarily by $\mathrm{OH}$ oxidation and is a precursor of greenhouse gases carbon dioxide $\left(\mathrm{CO}_{2}\right)$ and tropospheric ozone $\left(\mathrm{O}_{3}\right)$, giving $\mathrm{CO}$ emissions an indirect radiative forcing of 0.2 $\mathrm{W} / \mathrm{m}^{2}$ [IPCC, AR4: Forster et al., 2007]. Due to its medium-scale lifetime (weeks to months) CO is a useful tracer of pollution since it is transported globally, but is not evenly mixed in the atmosphere, allowing measurements of elevated $\mathrm{CO}$ that are easily distinguished above background levels.

While development of the algorithms used to process MOPITT measurements began several years before launch, these activities continue to be important. The MOPITT retrieval algorithm has been steadily refined since launch because of the following experience:

(1) Measurements 'on-orbit' were somewhat different from pre-launch simulations;

(2) Quantifying and resolving radiance errors has required innovative methods and new analytical tools;

(3) Errors due to both instrumental and geophysical sources have been identified;

(4) Little was known about the global variability of $\mathrm{CO}$ concentrations before launch;

(5) Ancillary datasets required by the retrieval algorithm have improved during the mission;

(6) Instrumental changes (both sudden and gradual) have occurred since launch, requiring adaptive algorithm changes; and

(7) Users have provided feedback with respect to product deficiencies.

Validation defines the accuracy of the retrieval product and thereby guides retrieval algorithm development. The goal of validation is to quantify and analyze retrieval errors through systematic comparisons with independent and trusted datasets. Like retrieval algorithm development, validation is an ongoing long-term process. MOPITT validation relies principally on $\mathrm{CO}$ vertical profiles from aircraft in-situ measurements that represent diverse geophysical conditions and pollution levels. This letter discusses how MOPITT retrieval products have improved, as compared to validation data, during the mission as the result of retrieval algorithm changes.

\section{The MOPITT instrument}

The MOPITT instrument is a multi-channel thermal infrared (TIR) and near infrared (NIR) instrument on board the EOS-Terra satellite launched in December, 1999 into a sunsynchronous polar orbit with $\sim 10: 30$ am local time descending node equator crossing. MOPITT has horizontal spatial resolution around $22 \mathrm{~km} \mathrm{x}$ $22 \mathrm{~km}$ and a swath width around $640 \mathrm{~km}$, which allows global coverage every 3 days. MOPITT uses gas-cell correlation radiometry to detect atmospheric $\mathrm{CO}$ absorption at $4.6 \mu \mathrm{m}$ (TIR channels) and $2.3 \mu \mathrm{m}$ (NIR channels), [Drummond et al., 2010 and references therein]. Retrievals using the methane channels at $2.2 \mu \mathrm{m}$ have not been possible due to the issues described in Pfister et al. [2005]. The MOPITT data record covers March 2000 to present. Figure 1 shows a map of $\mathrm{CO}$ total column measurements indicating MOPITT daily coverage. 


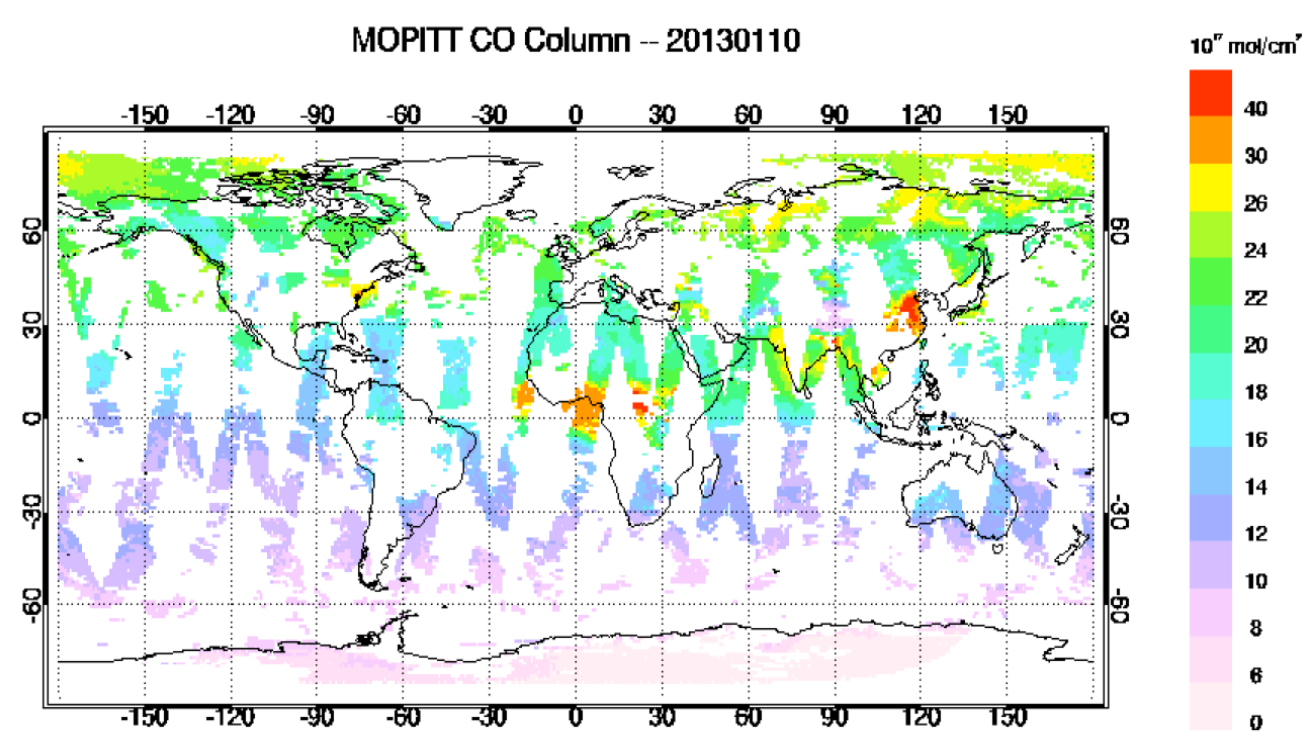

Figure 1. MOPITT CO column observations (in $10^{17}$ molecules $/ \mathrm{cm}^{2}$ ) for Jan 10, 2013.

III. MOPITT algorithm history

MOPITT versions V1 \& V2 products did not produce quantitative $\mathrm{CO}$ measurements. These regression-based retrievals produced qualitative maps that were useful for demonstrating MOPITT instrument functionality, but did not produce $\mathrm{CO}$ profiles with error characterization that could be used in further analysis, such as an optimal estimation (OE) product.

MOPITT V3 products were from OE retrievals that used a single global a priori profile with an a priori covariance (Sa) created from in situ profiles [Deeter et al., 2003, 2004, 2007b; Edwards et al., 2004; Emmons et al., 2004, 2007, 2009]. V3, V4 and V5 retrievals all use the NCEP (National Centers for Environmental Prediction) Global Data Assimilation System (GDAS) product for temperature and water vapor fields, with cloudy scenes discarded following cloud screening using both MOPITT radiances and collocated MODIS cloud detection. V3 processing also accounted for the loss of optical bench 1 (channels 1-4) in May 2001 with Phase I data produced from Mar. 2000 - May 2001 and Phase II data starting Aug. 2001 and thereafter.

MOPITT V4 was developed to address deficiencies in V3 that included a bias in Southern Hemisphere (SH) CO due to the use of a single global apriori; an apriori covariance that over estimated the correlation length; a limited training set of $\mathrm{CO}$ profiles in the fast radiative transfer (RT) algorithm that caused retrieval failures in extreme $\mathrm{CO}$ events; and $\mathrm{CO}$ retrieval parameters in volume mixing ratio (VMR) that did not represent the log-normal $\mathrm{CO}$ error statistics resulting in retrieval errors for low and high CO values [Deeter et al., 2007a]. The V4 algorithms addressed these issues by using apriori (profiles and covariances) from a MOZART monthly climatology [Emmons et al, 2010], an expanded training set for the forward model RT and $\log _{10}(\mathrm{VMR}) \mathrm{CO}$ parameters in OE retrievals. The V4 algorithm and validation are described in Deeter et al., [2010].

MOPITT V5 was developed mainly to provide new products that exploit the MOPITT NIR radiance measurements. These include the NIRonly [Deeter et al., 2009] and the multispectral TIR+NIR [Worden et al., 2010] products as well as the standard TIR-only product. In order to use the information from the NIR channel, it was necessary to fully understand all sources of measurement noise. This led to an improved measurement noise characterization described as "geophysical noise" in Deeter et al., [2011], that was implemented for all retrieval types. The V5 algorithm also includes a time-dependent radiative transfer model, which accounts for the slow, long-term instrumental degradation shown in Figure 2 by using time-interpolated gas cell parameters (rather than static values, as used in previous versions). Another change in V5 was a simplification in mapping the retrieval levels, which resulted in the $\mathrm{CO}$ vertical profile product defined over pressure layers rather than on levels. Finally, V5 has an improved co-alignment of MODIS data in the cloud detection algorithm. 
V5 validation results are presented in Deeter et al., [2012; 2013]. This improved dependence with time for the validation results has made it possible to compute decadal trends for $\mathrm{CO}$ using MOPITT data and compare these to other satellite CO measurements [Worden et al., 2013].

MOPITT V6 (to be delivered in 2013) algorithm changes are more incremental than V5, but address some important deficiencies of the previous versions. V6 uses the MERRA reanalysis [Rienecker et al., 2011] for water vapor, atmospheric temperature and surface temperature ( $\mathrm{H} 2 \mathrm{O}, \mathrm{T}, \mathrm{T}$ surf) to improve the spatial resolution $\left(0.66^{\circ} \times 0.5^{\circ}\right.$ vs. $\left.1^{\circ} \times 1^{\circ}\right)$, the time resolution for $\mathrm{T}$ surf ( $1 \mathrm{hr}$. vs. $6 \mathrm{hr}$.) and problems with missing values as compared to the NCEP fields. MERRA also has more accurate values (actual skin temperatures) for the T_surf initial guess used in MOPITT retrievals. In addition, V6 will correct a small geolocation error identified in the previous versions that resulted from a misalignment in MOPITT pointing angles with respect to the TERRA frame of reference. Finally, V6 will use a new climatology based on 2000-2009 simulations from CAM-Chem [Lamarque et al., 2012] that is more representative of the MOPITT data record than the previous V4 \& V5 climatology simulations that covered 1997-2004.

IV. Algorithm responses to instrument anomalies Figure 2 shows a time series since launch for the pressure in LMC3 (length modulated cell \#3) indicating sudden anomalies as well as a slow drift due mostly to long term instrument cooling [Drummond et al., 2010]. The first cooler failure in May 2001 resulted in the loss of optical bench \#1, however, MOPITT was able to continue measuring $\mathrm{CO}$ using the remaining 4 channels on optical bench \#2, with adjustments to the algorithms. The L1 and L2 algorithms also required adjustments after the sieve heater anomaly in Oct. 2009, and reverted to the preanomaly versions once the sieve heater began working again. No discontinuities in the data values or quality were detected once the algorithms were implemented.

\section{MOPITT algorithm changes responding to instrument anomalies}

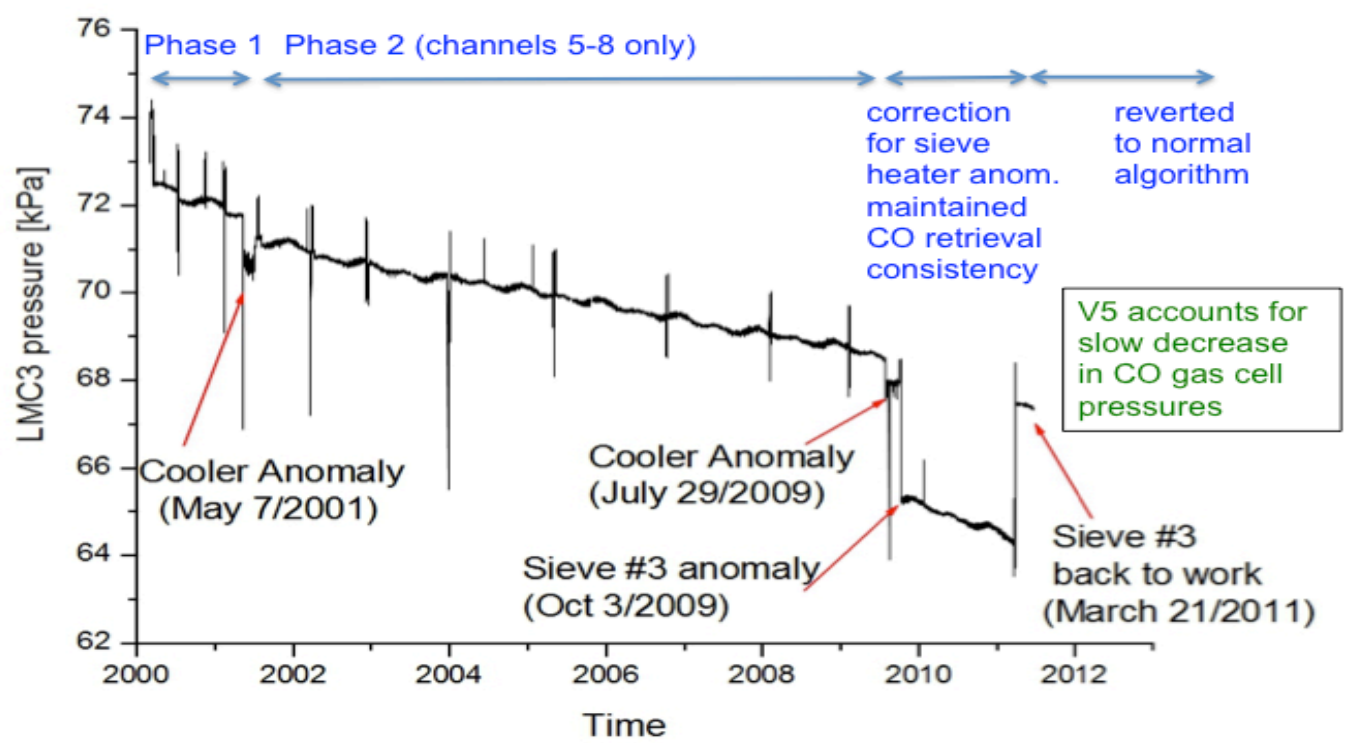

Figure 2. MOPITT pressure vs. time since launch for LMC3. The pressure change is slow ( 5\% in 10 years). Phase I represents MOPITT data with both optical benches operational; Phase II, after the cooler anomaly in May, 2001 uses only 1 optical bench. A transient molecular sieve heater fault in 2009 lowered the sieve temperature and pressure dropped $\sim 6 \%$, but corrections in L1 and L2 algorithms maintained data continuity and quality until normal operations were resumed on the restart in 2011. The spikes correspond to decontamination and calibration operations. The current trend is about 1\% pressure loss per year. (Courtesy of F. Nichitiu, U. Toronto). 


\begin{abstract}
V. Conclusions
On-orbit performance for satellite instruments will always present challenges to algorithm developers compared to the expectations from simulations and ground calibration activities. Although it has operated successfully since 2000, the MOPITT instrument has had instrument anomalies as well as very slow degradation that required adaptive algorithms. Better characterization of instrument performance, such as understanding geophysical noise, has allowed the MOPITT team to exploit both TIR and NIR channels, providing unprecedented sensitivity to near-surface CO. Improvements to the MOPITT retrieval methods and ancillary datasets have also improved accuracy as compared to longterm validation data. Given the current state of MOPITT health, the outlook for tracking $\mathrm{CO}$ trends for $>13$ years is very promising.
\end{abstract}

\section{ACKNOWLEDGEMENTS}

The MOPITT project is supported by the NASA Earth Observing System (EOS) Program. The MOPITT team also acknowledges support from the Canadian Space Agency (CSA), the Natural Sciences and Engineering Research Council (NSERC) and Environment Canada, along with the contributions of COMDEV (the prime contractor) and ABB BOMEM. NCAR is sponsored by the National Science Foundation.

\section{REFERENCES}

[Deeter et al., 2003] Deeter, M. N., L. K. Emmons, G. L. Francis, D. P. Edwards, J. C. Gille, J. X. Warner, B. Khattatov, D. Ziskin, J.-F. Lamarque, S.-P. Ho, V. Yudin, J.-L. Attié, D. Packman, J. Chen, D. Mao, and J. R. Drummond (2003). Operational carbon monoxide retrieval algorithm and selected results for the MOPITT instrument. J. Geophys. Res. (Atmospheres), 108:4399.

[Deeter et al., 2004a] Deeter, M. N., L. K. Emmons, D. P. Edwards, J. C. Gille, and J. R. Drummond (2004a). Vertical resolution and information content of $\mathrm{CO}$ profiles retrieved by MOPITT. Geophys. Res. Lett., 31:15112.

[Deeter et al., 2004b] Deeter, M. N., et al. (2004b). Evaluation of operational radiances for the Measurements of Pollution in the Troposphere (MOPITT) instrument CO thermal band channels, J. Geophys. Res., 109, D03308, doi:10.1029/2003JD003970.

[Deeter et al., 2007a] Deeter, M. N., D. P. Edwards, and J. C. Gille (2007a). Retrievals of carbon monoxide profiles from MOPITT observations using lognormal a priori statistics. $J$. Geophys. Res. (Atmospheres), 112:11311.

[Deeter et al., 2007b] Deeter, M. N., D. P. Edwards, J. C. Gille, and J. R. Drummond (2007b). Sensitivity of MOPITT observations to carbon monoxide in the lower troposphere. $J$. Geophys. Res., 112:24306.

[Deeter et al., 2009] Deeter, M. N., D. P. Edwards, J. C. Gille, and J. R. Drummond (2009). CO retrievals based on MOPITT nearinfrared observations, J. Geophys. Res., 114, D04303, doi:10.1029/2008JD010872.

[Deeter et al., 2010] Deeter, M.N., D. P. Edwards, J. C. Gille, L. K. Emmons, G. Francis, S.-P. Ho, D. Mao, D. Masters, H. Worden, J. R. Drummond and P. Novelli (2010). The MOPITT Version 4 CO Product: Algorithm Enhancements, Validation, and Long-Term Stability, J. Geophys. Res., 115, D07306, doi:10.1029/2009JD013005.

[Deeter et al., 2011] Deeter, M. N., H. M. Worden, J. C. Gille, D. P. Edwards, D. Mao, and J. R. Drummond (2011). MOPITT multispectral CO retrievals: Origins and effects of geophysical radiance errors, J. Geophys. Res., 116, D15303, doi:10.1029/2011JD015703.

[Deeter et al., 2012] Deeter, M. N., H. M. Worden, D. P. Edwards, J. C. Gille, and A. E. Andrews (2012). Evaluation of MOPITT Retrievals of Lower-tropospheric Carbon Monoxide over the United States, J. Geophys. Res., doi:10.1029/2012JD017553.

[Deeter et al., 2013] Deeter, M. N., S. MartınezAlonso, D. P. Edwards, L. K. Emmons, J. C. Gille, H. M. Worden, J. V. Pittman, B. C. Daube and S. C. Wofsy (2013).Validation of MOPITT Version 5 Thermal-Infrared, Near-Infrared, and Multispectral Carbon Monoxide Profile Retrievals for 2000-2011, J. Geophys. Res., 118, 1- 16, doi:10.1002/jgrd.50272.

[Drummond et al., 2010] Drummond, J. R., J. Zou, F. Nichitiu, J. Kar, R. Deschambaut, J. Hackett (2010). A review of 9-year performance and operation of the MOPITT instrument, J. Adv. Space Res., doi:10.1016/j.asr.2009.11.019.

[Edwards et al., 2004] Edwards, D.P., L. K. Emmons, D. A. Hauglustaine, D. A. Chu, J. C. Gille, Y. J. Kaufman, G. Pétron, L. N. Yurganov, L. Giglio, M. N. Deeter, V. Yudin, D. C. Ziskin, J. Warner, J.-F. Lamarque, G. L. Francis, S. P. Ho, D. Mao, J. Chen, E. I. Grechko, and J. R. Drummond (2004), Observations of carbon monoxide and aerosols from the Terra satellite: Northern Hemisphere variability. J. Geophys. Res. (Atmospheres), 109:24202. 
[Emmons et al., 2004] Emmons, L. K., M. N. Deeter, J. C. Gille, D. P. Edwards, J.-L. Attié, J. Warner, D. Ziskin, G. Francis, B. Khattatov, V. Yudin, J.-F. Lamarque, S.-P. Ho, D. Mao, J. S. Chen, J. Drummond, P. Novelli, G. Sachse, M. T. Coffey, J. W. Hannigan, C. Gerbig, S. Kawakami, Y. Kondo, N. Takegawa, H. Schlager, J. Baehr, and H. Ziereis (2004). Validation of Measurements of Pollution in the Troposphere (MOPITT) CO retrievals with aircraft in situ profiles. J. Geophys. Res. (Atmospheres), 109:3309.

[Emmons et al., 2007] Emmons, L. K., G. G. Pfister, D. P. Edwards, J. C. Gille, G. Sachse, D. Blake, S. Wofsy, C. Gerbig, D. Matross, and P. Nédélec (2007). Measurements of Pollution in the Troposphere (MOPITT) validation exercises during summer 2004 field campaigns over North America. J. Geophys. Res. (Atmospheres), 112:12.

[Emmons et al., 2009] Emmons, L. K., Edwards, D. P., Deeter, M. N., Gille, J. C., Campos, T., Nédélec, P., Novelli, and G. Sachse, (2009). Measurements of Pollution In The Troposphere (MOPITT) validation through 2006, Atmos. Chem. Phys., 9, 1795-1803, doi:10.5194/acp-91795-2009.

[Emmons et al, 2010] Emmons, L. K., S. Walters, P. G. Hess, J.-F. Lamarque, G. G. Pfister, D. Fillmore, C. Granier, A. Guenther, D. Kinnison, T. Laepple, J. Orlando, X. Tie, G. Tyndall, C. Wiedinmyer, S. L. Baughcum, and S. Kloster (2010). Description and evaluation of the Model for Ozone and Related chemical Tracers, version 4 (MOZART-4) Geosci. Model Dev., 3, 43-67.

[Forster et al., 2007] Forster, P., V. Ramaswamy, P. Artaxo, T. Berntsen, R. Betts, D.W. Fahey, J. Haywood, J. Lean, D.C. Lowe, G. Myhre, J. Nganga, R. Prinn, G. Raga, M. Schulz and R. Van Dorland (2007). Changes in Atmospheric Constituents and in Radiative Forcing. In: Climate Change 2007: The Physical Science Basis. Contribution of Working Group I to the Fourth Assessment Report of the Intergovernmental Panel on Climate Change [Solomon, S., D. Qin, M. Manning, Z. Chen, M. Marquis, K.B. Averyt, M.Tignor and H.L. Miller (eds.)]. Cambridge University Press, Cambridge, United Kingdom and New York, NY, USA. (IPCC AR4)

[Lamarque et al., 2012] Lamarque, J.-F., et al., (2012). CAM-chem: description and evaluation of interactive atmospheric chemistry in the Community Earth System Model, Geosci. Model Dev., 5, 369-411, 2012, doi:10.5194/gmd-5-3692012
[Pfister et al., 2005] Pfister, G., J. C. Gille, D. Ziskin, G. Francis, D. P. Edwards, M. N. Deeter, and E. Abbott (2005), Effects of a Spectral Surface Reflectance on Measurements of Backscattered Solar Radiation: Application to the MOPITT Methane Retrieval, J. Atmos. Oceanic Technol., 22, 566, doi:10.1175/JTECH1721.1

[Rienecker et al., 2011] Rienecker, M.M., M.J. Suarez, R. Gelaro, R. Todling, J. Bacmeister, E. Liu, M.G. Bosilovich, S.D. Schubert, L. Takacs, G.-K. Kim, S. Bloom, J. Chen, D. Collins, A. Conaty, A. da Silva, et al., (2011). MERRA: NASA's Modern-Era Retrospective Analysis for Research and Applications. J. Climate, 24, 36243648, doi:10.1175/JCLI-D-11-00015.1

[Worden et al., 2010] Worden, H. M., M. N. Deeter, D. P. Edwards, J. C. Gille, J. R. Drummond, and P. P. Nédélec (2010). Observations of near-surface carbon monoxide from space using MOPITT multispectral retrievals, J. Geophys. Res., 115, D18314, doi:10.1029/2010JD014242.

[Worden et al., 2013] Worden, H. M., et al., (2013). Decadal record of satellite carbon monoxide observations, Atmos. Chem. Phys., 13, 837-850, 2013 doi:10.5194/acp-13-837-2013. 